\title{
A COMPOSITE REFERENCE SECTION FOR TERMINAL PROTEROZOIC STRATA OF SOUTHERN NAMIBIA
}

\author{
BEVERLY Z. SAYLOR ${ }^{1 *}$, ALAN J. KAUFMAN ${ }^{2}$, JOHN P. GROTZINGER $^{1}$, AND FRANK URBAN ${ }^{3}$ \\ ${ }^{1}$ Department of Earth, Atmospheric, and Planetary Sciences, Massachusetts Institute of Technology, Cambridge, Massachusetts 02139, U.S.A. \\ ${ }^{2}$ Botanical Museum, Harvard University, 26 Oxford Street, Cambridge, Massachusetts 02138, U.S.A. \\ ${ }^{3}$ Department of Geology, Hobart College, Geneva, New York, U.S.A. \\ * Present address: Department of Geological Sciences, Case Western Reserve University, Cleveland, Ohio 44105, U.S.A.
}

\begin{abstract}
Integrated sequence stratigraphic and chemostratigraphic data yield a framework for correlations of stratigraphic units in the terminal Proterozoic to Cambrian Witvlei and Nama Groups of Namibia. Coupled with precise $\mathrm{U}-\mathrm{Pb}$ zircon age constraints, these correlations make it possible to construct a composite reference section for use in calibrating terminal Proterozoic chronostratigraphy. The Namibian reference section starts with two distinct glacial horizons and extends up to within 1 million years of the Proterozoic-Cambrian boundary. The two glacial horizons may represent each of two distinct Varanger-age glaciations better known from the North Atlantic region. From the higher of the two glacial horizons up, the composite stratigraphy preserves one of the thickest and most complete available records of carbon-isotope variability in post-Varanger terminal Proterozoic seawater. Four carbon-isotope chemostratigraphic intervals are recognized: (1) a postglacial negative $\delta^{13} \mathrm{C}$ excursion (Npg interval); (2) a rising interval (Pr interval) of increasing positive $\delta^{13} \mathrm{C}$ values; (3) a falling interval (Pf interval) characterized by decreasing positive $\delta^{13} \mathrm{C}$ and culminating in near zero or negative values; and (4) an interval of moderately positive, relatively invariant $\delta^{13} \mathrm{C}$ values (I interval) that extends up to the unconformity that contains the ProterozoicCambrian boundary. Each of these chemostratigraphic intervals can be recognized in widely separated correlative sections around the world. By comparing sediment accumulation rate in the radiometrically calibrated Namibian stratigraphy with sediment accumulation rates in correlative sections in Arctic Canada and Oman, a maximum age of $564 \mathrm{Ma}$ is estimated for the end of the younger Varanger glaciation, $25 \mathrm{~m}$.y. younger than previous estimates.
\end{abstract}

\section{INTRODUCTION}

Large secular variations in the carbon- and strontium-isotope composition of terminal Proterozoic seawater, now preserved in sedimentary carbonates and organic matter, make it possible to correlate widely separated sections around the world, providing a framework for piecing together a terminal Proterozoic chronostratigraphy (Kaufman and Knoll 1995; Kaufman et al. 1997). On the basis of isotopic correlations, two distinct episodes of Varanger (Knoll and Walter 1992) glaciation can be distinguished (Kaufman et al. 1997), each bracketed by strongly positive and negative $\delta^{13} \mathrm{C}$ values.

Isotope stratigraphy, by itself, can provide only relative age constraints. Coupled with absolute age constraints from $\mathrm{U}-\mathrm{Pb}$ zircon geochronology, the isotope curves become powerful tools for both ordering and timing events. For example, U-Pb zircon dates from Namibia (Grotzinger et al. 1995) and Siberia (Bowring et al. 1993), combined with the fine chronostratigraphic resolution provided by isotope excursions, constrain the age of the Proterozoic-Cambrian boundary (ca. $543 \mathrm{Ma}$ ) to within 1 million years. The timing of older events remains unclear, however. At present the best estimates for the timing of Varanger ice ages come from $\mathrm{U}-\mathrm{Pb}$ zircon dates on volcanic rocks that lie thousands of meters below $(606+3.7 /$ -2.9 Ma; Krogh et al. 1988; 602 \pm 3 Ma; Kaye and Zartman 1980) and thousands of meters above (565 $\pm 5 \mathrm{Ma}$; Benus 1988) inferred Varangerequivalent tillite in the Avalon terrane of Newfoundland and Massachusetts
(Myrow 1995). In the absence of a chemostratigraphic framework, however, it is unclear which glaciation the Avalon tillite represents.

In this paper sequence stratigraphy and carbon-isotope chemostratigraphy are combined to correlate stratigraphic units of terminal Proterozoic age on the Kalahari craton of Namibia. A composite reference section is constructed that extends from postglacial transgression at the end of the younger Varanger ice age up to within a million years of the ProterozoicCambrian boundary. The upper part of the resulting isotope profile is directly tied to U-Pb zircon ages (Grotzinger et al. 1995) and hence, through correlation, places constraints on the ages of other terminal Proterozoic successions worldwide. These data significantly compress the duration of key features of terminal Proterozoic chronostratigraphy relative to previous estimates; they suggest that the end of the Varanger glacial epoch may be much younger than originally inferred.

\section{GEOLOGY AND AGE CONSTRAINTS}

Terminal Proterozoic strata on the Kalahari Craton of Namibia, comprising the Witvlei and lower Nama groups and their correlatives (Fig. 1), contain the key features of known terminal Proterozoic chronostratigraphy, including glacial horizons (Hoffmann 1989), a diverse fossil record (e.g., Crimes and Germs 1982; Germs 1983; Grant 1990; Grotzinger et al. 1995), and strong carbon- and strontium-isotope excursions recorded in well-preserved carbonate rocks (Kaufman et al. 1991; Derry et al. 1992; Kaufman et al. 1993, Kaufman et al. 1997).

Modern and ancient geographic features segregate terminal Proterozoic outcrops of the Kalahari craton into four areas: (1) the Witvlei sub-basin near Gobabis; (2) the Naukluft Nappe Complex; and (3) the northern and (4) southern Nama sub-basins. The Witvlei Group, the oldest part, is exposed in the area near Gobabis and is interpreted as a passive-margin succession (Figs. 1, 2A; Hoffmann 1989; Hegenberger 1993). These rocks lie directly above glacial diamictite of the Blaubeker Formation and are overlain by the lower Nama Group. The Naukluft Nappe Complex is a series of nappes that have been thrusted over autochthonous strata of the Nama Group (Fig. 1; Hartnady 1978). They contain both Witvlei- and Namaequivalent strata, and a glaciogenic unit, the Blässkrans Formation (Fig. 2B; Hoffmann 1989; Hoffmann et al. 1995; Kaufman et al. 1997). The fossiliferous Nama Group overlies the Witvlei Group in the Gobabis area but is best preserved to the south (Fig. 1). Much of the Nama Group was deposited in a foreland basin that developed during convergence along the bordering Damara and Gariep compressional belts (Germs 1983; Gresse and Germs 1993; Germs 1995). During deposition of lower Nama group, the Nama basin was partitioned into northern and southern sub-basins by a basement arch culminating near Osis (Germs 1983).

The Proterozoic part of the Nama Group comprises the Kuibis and most of the Schwarzrand subgroups. Terminal Proterozoic fossils, including Ediacaran-type fossils (Germs 1972; Germs 1983; Grotzinger et al. 1995, Narbonne et al. 1997), Vendotaenids (Germs et al. 1986), and Cloudina (Germs 1983; Grant 1990), plus other calcified fossils (Grotzinger et al. 1995) are present both north and south of Osis (Fig. 2). The stratigraphically highest known Ediacaran-type fossils lie $\sim 60 \mathrm{~m}$ below the Proterozoic-Cambrian boundary, a regionally extensive erosional unconformity near the top of 


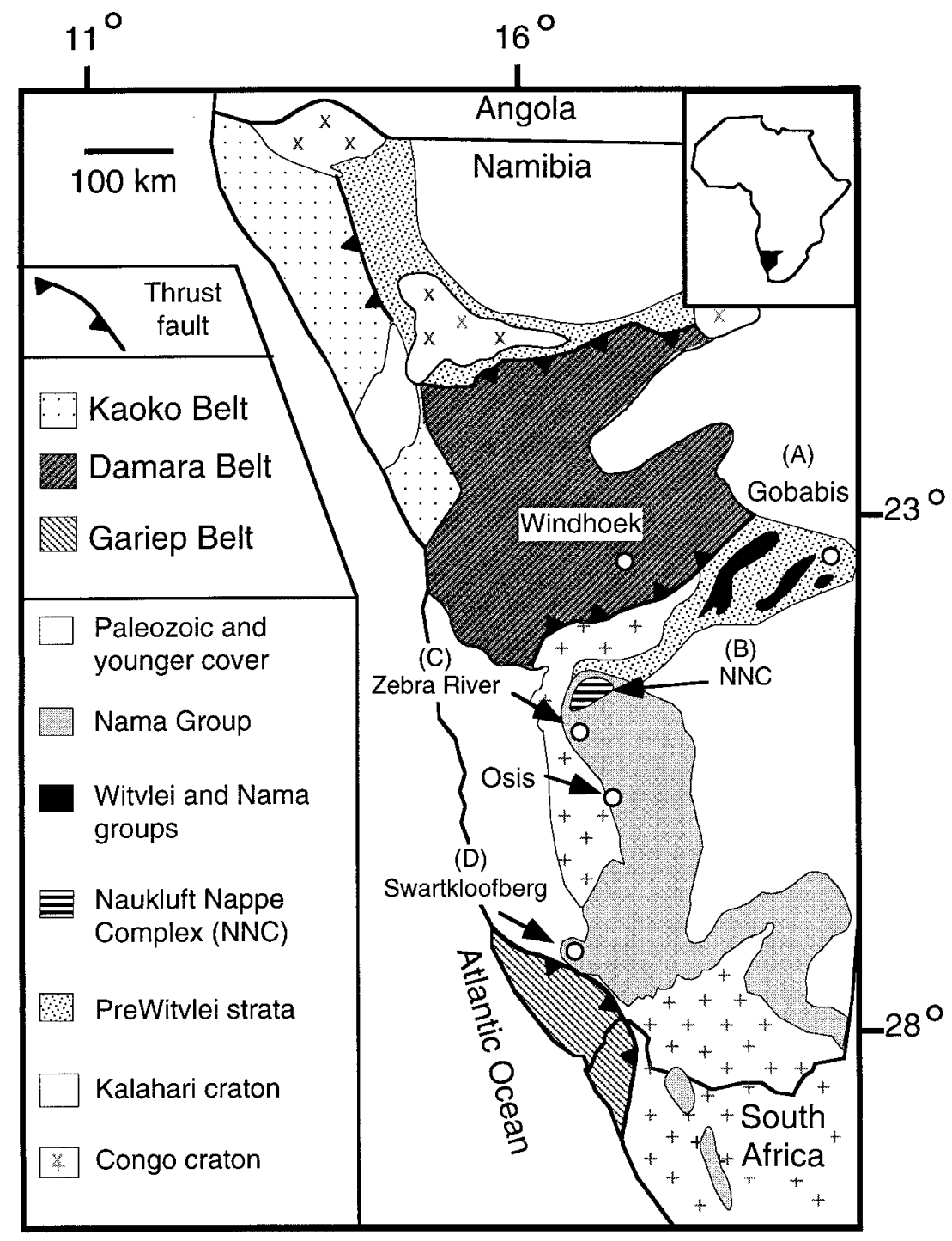

Fig. 1.-Map showing exposures of the Nama and Witvlei groups in Namibia and location of measured sections in Figure 2. the southern Schwarzrand Subgroup (Fig. 2D; Grotzinger et al. 1995; Saylor and Grotzinger 1997; Narbonne et al. 1997).

$\mathrm{U}-\mathrm{Pb}$ zircon ages for ash beds intercalated in the Nama Group provide high-resolution absolute age control (Fig. 2; Grotzinger et al. 1995). The oldest dated ash bed $(548 \pm 1 \mathrm{Ma})$ is from the Kuibis Subgroup in the northern sub-basin; the rest are from the Schwarzrand Subgroup in the southern sub-basin. An ash bed from $130 \mathrm{~m}$ below the Proterozoic-Cambrian boundary in the southern sub-basin yielded an age 543.3 $\pm 1 \mathrm{Ma}$ (Fig. 2D), the same age, within the limits of error, as lowermost Cambrian volcanic rocks in Siberia (Bowring et al. 1993), suggesting that the Proterozoic part of the succession extends to within one million years of the Proterozoic-Cambrian boundary.

\section{METHODS}

Here, a composite chronostratigraphy is constructed by combining the stratigraphic record from each of the four exposure areas. Because stratigraphic units cannot be traced directly between the four regions, reconstruction relies on sequence stratigraphic and chemostratigraphic correlations that supplement and refine available lithostratigraphic and biostratigraphic constraints (Figs. 2, 3).

\section{Sequence Stratigraphy}

Numerous sections have been measured and described in each of the four geographic areas (Germs 1983; Hegenberger 1993; Saylor 1993, 1996; Saylor et al. 1995). Interpretations of facies stacking patterns are based largely on indicators of depositional energy. Lithofacies associations are subdivided into four main environmental zones (Fig. 4; e.g., Kerans and Tinker 1997): (1) shoreline and/or tidal flat (restricted, nearshore environment); (2) upper shoreface (above fair-weather wave base; (3) middle shoreface (between storm and fair-weather wave base; and (4) lower shoreface (below wave base). Valley-fill and glaciogenic facies associations are also distinguished.

Depositional sequences are composed of relatively conformable stratigraphic successions, bounded by unconformities or their correlative conformities (Van Wagoner et al. 1988; Sarg 1988; Kerans and Tinker 1997). Sequence boundaries are recognized on the basis of regionally extensive surfaces or zones, marked by either (1) erosion or valley incision, (2) an abrupt change in facies, or (3) a transition from regressive to transgressive facies stacking patterns. Sequence boundaries in the southern Nama subbasin have been traced laterally for up to hundreds of square kilometers (Saylor et al. 1995; Saylor 1996). 

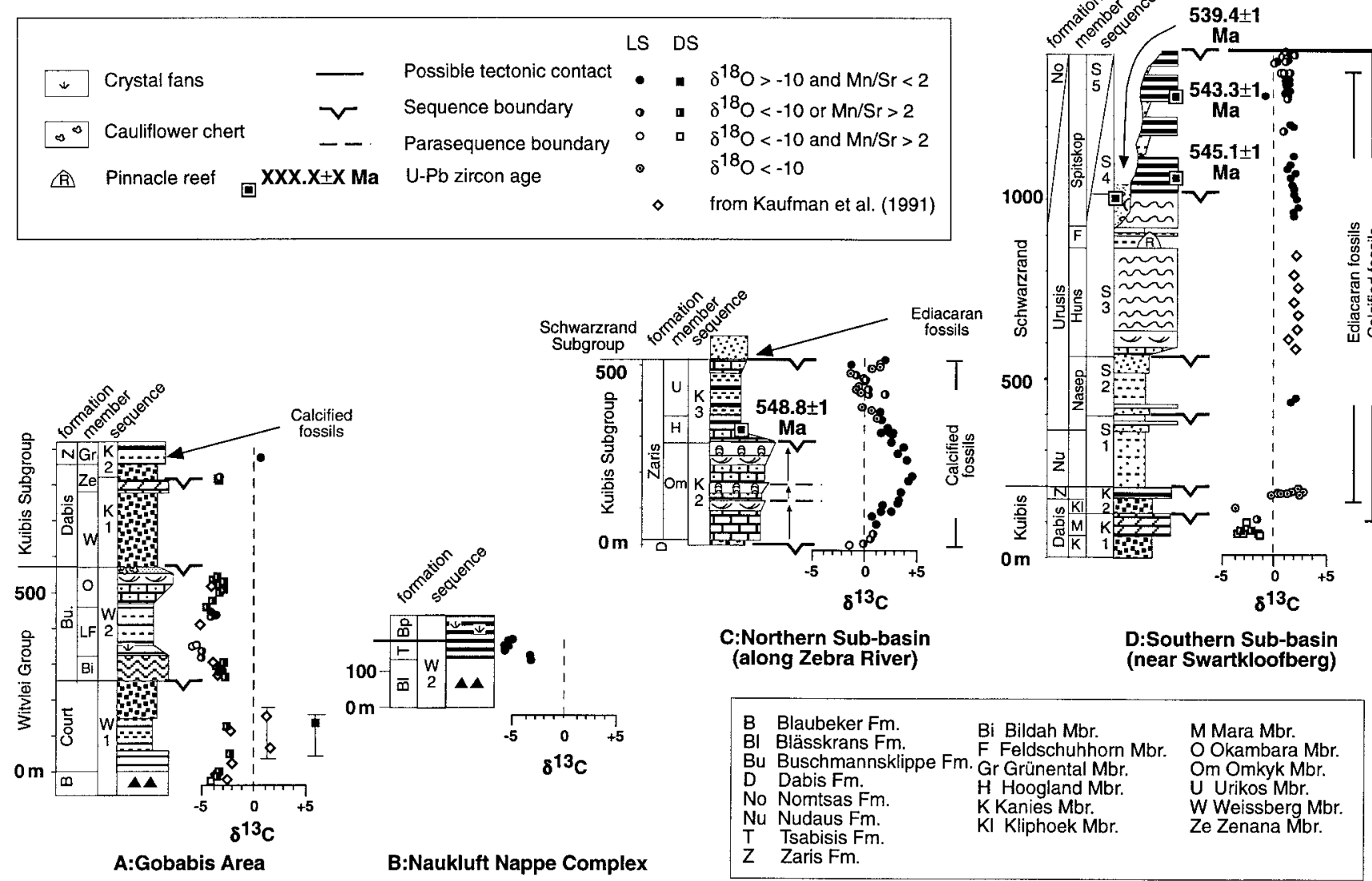

FIG. 2.-Stratigraphic columns and corresponding carbon-isotope data through the Witvlei Group and Kuibis and Schwarzrand subgroups. Carbon-isotope data from Kaufman et al. (1991) and data from this study for the Court and Dabis formations in the Gobabis area (A) are from multiple sections and are plotted in approximate positions relative to the generalized composite column. Other data are tied directly to measured sections. The measured section from near Swartkloofberg is a composite. See Figure 1 for locations. (Note: Position of Naukluft Nappe Complex is not palinspastically restored)

\section{Carbon-Isotope Chemostratigraphy}

In general, the finest-grained, most pristine-looking samples were collected at intervals of 3-10 m along measured stratigraphic sections (Figs. 2, 3). Exceptions are samples from the lower Witvlei Group (Court Formation) and the Nama Group in the Gobabis area, which were collected from multiple exposures. Consequently, isotope values for these samples are plotted only in approximate positions relative to a generalized stratigraphic column (Fig. 2A). Isotope data from this study (see Appendix) are supplemented by data from Kaufman et al. (1991), which have been regrouped according to collection location and plotted relative to measured stratigraphic sections (Figs. 2, 3).

Samples were evaluated petrographically and geochemically for diagenetic alteration following methods reviewed by Kaufman and Knoll (1995). Isotopic and elemental analyses followed methods described by Kaufman et al. (1991), Derry et al. (1992), Narbonne et al. (1994), and Kaufman and Knoll (1995).

Samples consist of fine-grained limestone or dolostone, or more rarely of intraclast or pellet packstone/grainstone. Micrite and microspar were preferentially sampled during drilling. Fluorescence under cathodoluminescence was variable, and highly luminescent areas were avoided during microsampling. $\delta^{18} \mathrm{O}$ values range between $-0.1 \%$ and $-16.7 \%$, but most lie between $-5 \%$ and $-10 \%$. $\mathrm{Mn} / \mathrm{Sr}$ ratios range between 0.05 and 22.24; most are less than 2 , and nearly all are less than $10 . \mathrm{Fe} / \mathrm{Sr}$ ratios range between 1.3 and 24.3; most are less than 10. Following Narbonne et al. (1994), samples with $\delta^{18} \mathrm{O}>-10 \%$ and $\mathrm{Mn} / \mathrm{Sr}<2$ are considered to be the least altered. According to these criteria, carbonate samples from the Gobabis area show the most evidence for alteration (Fig. 2). Nonetheless, in most cases these samples passed at least one of the diagenetic tests. In addition, $\delta^{13} \mathrm{C}$ values for samples that failed one of the tests agree well with $\delta^{13} \mathrm{C}$ values from stratigraphically nearby samples that passed both, suggesting minimal $\delta^{13} \mathrm{C}$ alteration. Smooth and consistent variation of $\delta^{13} \mathrm{C}$ values in each of the areas reveals clear stratigraphic trends with no evidence for lithology or facies control (Figs. 2, 3). Thus, as a whole, the isotope patterns documented in each of the studied areas are interpreted to record near-primary variations in the carbon-isotope composition of seawater.

\section{STRATIGRAPHY AND CORRELATIONS}

\section{Witvlei Group and Equivalents}

The Witvlei Group is restricted to the Gobabis area (Figs. 1, 2), with stratigraphic equivalents preserved in the Naukluft Nappe Complex. It consists of the Court and Buschmannsklippe formations and an intervening angular unconformity. This unconformity, which subdivides the Witvlei Group into depositional sequences W1 and W2, may correlate with the glaciogenic Blässkrans Formation of the Naukluft Nappe Complex (Hoffmann 1989; Hoffmann et al. 1995; Kaufman et al. 1997).

Sequence W1-Court Formation.-The Court Formation (Fig. 2A) has a limited lateral extent and pinches out to the north and west, where it is overstepped by the Buschmannsklippe Formation. It is a maximum of 200 


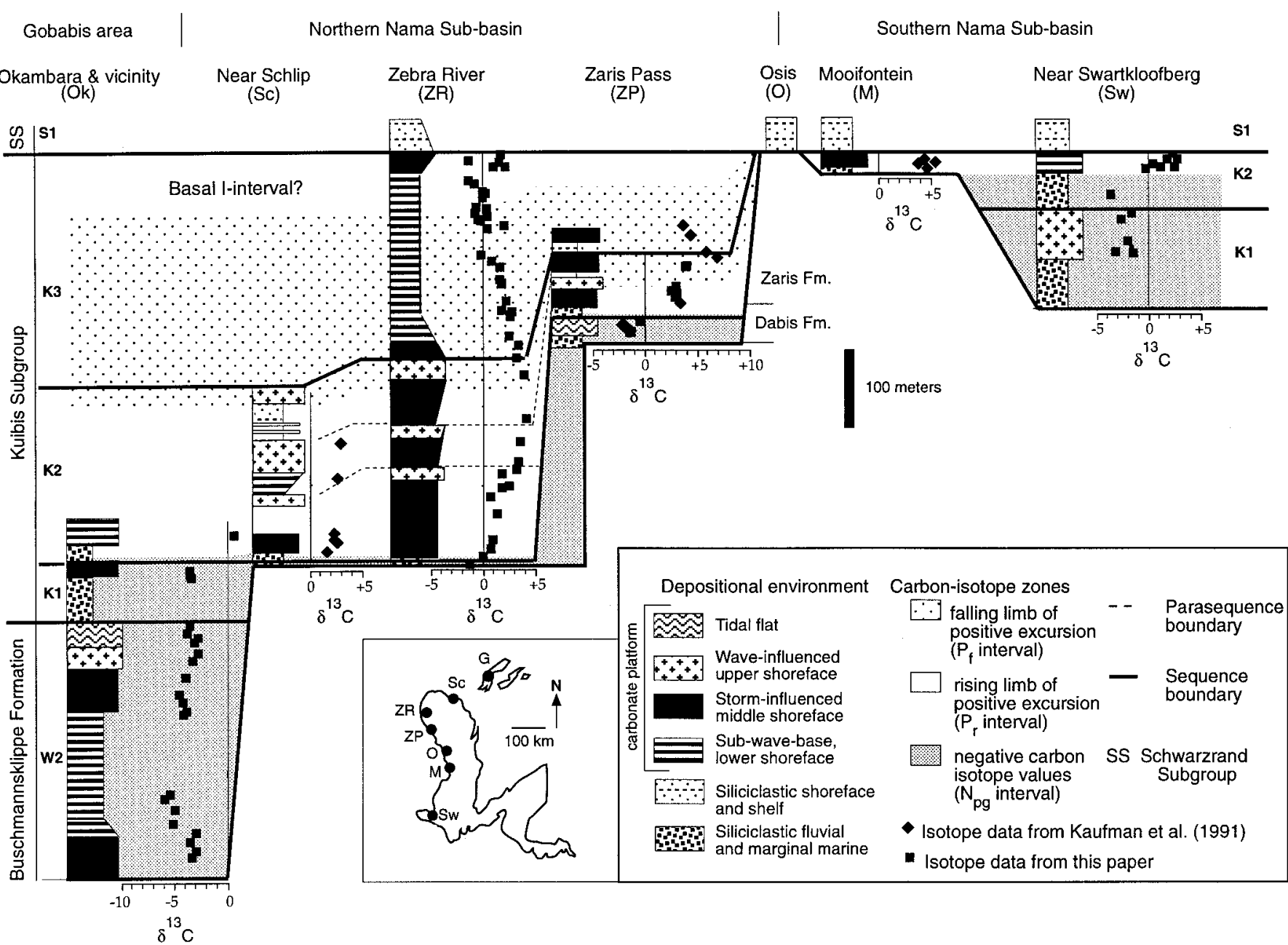

FIg. 3.-Measured stratigraphic sections and carbon-isotope data along a north-south transect of the Buschmannsklippe Formation and the Kuibis Subgroup showing chemostratigraphic and sequence stratigraphic correlations. Carbon-isotope data from Kaufman et al. (1991) have been replotted onto measured sections. Inset shows locations of sections relative to outline of exposures of the Nama and Witvlei Groups.

$m$ thick and consists of laminated carbonate at the base, overlain by heterolithic shale, sandstone, and dolostone, followed by coarse sandstone with locally developed conglomerate and stromatolitic dolostone (Hegenberger 1993). Hegenberger (1993) recognized typical marine sedimentary features such as intraclast conglomerate and ooid grainstone but suggested that the limited extent of the Court Formation may indicate deposition in a restricted or lacustrine basin.

Sequence W2-Buschmannsklippe Formation.-The Buschmannsklippe Formation thickens northwestward across the Gobabis area to a maximum of $200 \mathrm{~m}$ (Fig. 2A). The Bildah Member, at its base, consists of massive and laminated, fine-grained, pink/tan dolostone. It is characterized by distinctive meter-high, irregular domes and slump structures, which are truncated by enigmatic vertical tubes (Hegenberger 1987). The Bildah Member grades upward into thin-bedded pink/tan limestone and purple shale, siltstone and sandstone of the La Fraque Member. In situ fans composed of precipitated layers of upward-divergent calcite near the La Fraque base are interpreted to have precipitated directly on the sea floor, most likely as aragonite (e.g., Grotzinger and Knoll 1995; Sumner and Grotzinger 1996), and to correspond to the zone of maximum flooding.

Sedimentary features indicative of storm reworking, including edgewiseoriented intraclast carbonate conglomerate and hummocky cross-stratified sandstone, increase in abundance upward through the La Fraque Member as facies grade into heterolithic carbonate and siliciclastic interbeds of the lower Okambara Member. The Okambara Member, in turn, shoals upward through upper-shoreface cross-stratified grainstone into a restricted, tidalflat assemblage of microbial dolostone with cauliflower chert (probably replaced anhydrite; e.g., Milliken 1979), grainstone, and sandstone. The contact with sandstone of the basal Nama Group (Weissberg Member) is gradational. Small wave-ripple forms and desiccation cracks on bed tops indicate a continued tidal-flat setting.

The Buschmannsklippe Formation is interpreted as a transgressive-regressive succession that forms a depositional sequence (Hegenberger 1993). The homogeneity of the fine-grained carbonate in the lower Buschmannsklippe Formation, the domal laminites with truncating tube-like structures, and the evidence for direct precipitation of carbonate on the sea floor all compare well with distinctive carbonate units overlying Proterozoic glacial diamictite worldwide (Williams 1979; Aitken 1991; Fairchild and Spiro 1987; Hegenberger 1987; Fairchild and Hambrey 1995; Grotzinger and Knoll 1995; Kennedy 1996), and in particular with carbonate overlying the Blässkrans diamictite in the Naukluft Nappe Complex (Hoffmann 1989; Hoffmann et al. 1995). The Bildah Member is similarly interpreted to record transgression, consistent with deposition during postglacial sealevel rise. The upper La Fraque Member and the Okambara Member shoal upward. Significantly, the contact with the overlying Weissberg Member (ba- 


\begin{tabular}{|c|c|c|c|}
\hline 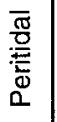 & 累 & $\begin{array}{l}\text { Microbial/fenestral } \\
\text { dolostone, grainstone } \\
\text { \& sandstone }\end{array}$ & $\begin{array}{l}\text { Interbedded digitate stromatolites or fenestal dolostone, intraclast/pelletal } \\
\text { grainstone, and medium to very coarse sandstone. Thin beds. Planar and ripple } \\
\text { lamination. Dessication cracks. }\end{array}$ \\
\hline \multirow{4}{*}{ 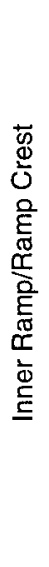 } & $\sqrt{\pi}$ & $\begin{array}{l}\text { Cross-stratified } \\
\text { grainstone }\end{array}$ & $\begin{array}{l}\text { Intraclast, pelletal or peloidal grainstone. Commonly dolomitized. Nested } \\
\text { trough cross-stratification. }\end{array}$ \\
\hline & 完穴勾 & $\begin{array}{l}\text { Stromatolitic buildup/ } \\
\text { biostrome }\end{array}$ & $\begin{array}{l}\text { Isolated bioherms or laterally extensive marker biostrome. Constructed of LLH } \\
\text { stromatolites with micrite and skeletal debris in fill. Stromatolites elongate in } \\
\text { NW-SE direction. }\end{array}$ \\
\hline & 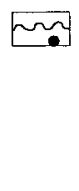 & $\begin{array}{l}\text { Stromatolite-grainstone } \\
\text { cycles }\end{array}$ & $\begin{array}{l}1 \text { to } 5 \mathrm{~m} \text { thick, upward-coarsening cycles. LLH stromatolites common at } \\
\text { cycle base. Stromatolite elongation direction SW-NE. Massive to } \\
\text { planar-laminated calcisiltite grades upward into coarse pelletal/intraclast } \\
\text { trough cross-stratified packstone to grainstone. Karst potholes with relief of } \\
1-2 \text { meters locally cap cycles. }\end{array}$ \\
\hline & 急 & $\begin{array}{l}\text { Irregularly laminated } \\
\text { fine dolostone }\end{array}$ & $\begin{array}{l}\text { Predominantly silt- and very fine sand-sized carbonate. Commonly dolomite. } \\
\text { Scour and drape lamination and ripple lamination common. Intraclast } \\
\text { conglomerate and mud cracks present but rare. }\end{array}$ \\
\hline \multirow{3}{*}{ 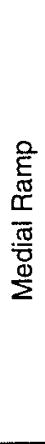 } & 空血 & $\begin{array}{l}\text { Massive and hummocky } \\
\text { cross-stratified } \\
\text { calcisiltite }\end{array}$ & $\begin{array}{l}\text { Medium- to thick-bedded calcisiltite. Massive with local scour and drape } \\
\text { features and hummocky cross-stratification. }\end{array}$ \\
\hline & 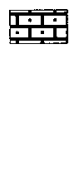 & Heterolithic interbeds & $\begin{array}{l}\text { Thin- to medium-interbedded limestone, very fine sandstone and shale. } \\
\text { Intraclast conglomerate (locally edgewise), hummocky cross-stratification or } \\
\text { coarse-grained ripples common. Carbonate composed of calcisiltite and } \\
\text { calcarenite. Skeletal parts are locally abundant in Kuibis Subgroup. Sandstone } \\
\text { and shale are pink to purple in Witvlei Group, green in Kuibis Subgroup. }\end{array}$ \\
\hline & 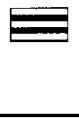 & Thin-bedded limestone & $\begin{array}{l}\text { Thin-bedded, fine-grained limestone. Rare to common intraclast conglomerate } \\
\text { beds with mounded tops. Locally present thrombolite or stromatolite columns, up } \\
\text { to } 2 \mathrm{~m} \text { tall. }\end{array}$ \\
\hline \multirow{4}{*}{ 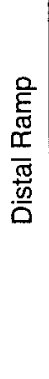 } & & $\begin{array}{l}\text { Laminated limestone with } \\
\text { domes and slumps }\end{array}$ & $\begin{array}{l}\text { Thinly laminated, calcilutite and calcisiltite. Laminae form irregular, } \mathrm{m} \text {-high } \\
\text { mounded stuctures. Laminae cut by vertical tubes, up to a few } \mathrm{cm} \text { wide and } \\
\text { several } \mathrm{m} \text { long, and filled with spar and/or sediment. }\end{array}$ \\
\hline & 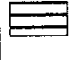 & Thin-laminated limestone & Thinly, evenly laminated calcisiltite and dololutite. Rare thin beds of calcarenite. \\
\hline & $+\cdots$ & Limestone and shale & $\begin{array}{l}\text { Thinly interbedded fine grained calcisiltite, dololutite and shale. Shale is pink to } \\
\text { purple in Buschmannsklippe Formation, green in Kuibis Subgroup. }\end{array}$ \\
\hline & $\therefore$ & Shale and limestone & $\begin{array}{l}\text { Purple (Buschmannsklippe Formation) or green (Kuibis Subgroup) shale with } \\
\text { subordinate thin to very thin beds of calcisiltite or calcarenite. }\end{array}$ \\
\hline \multirow{6}{*}{ 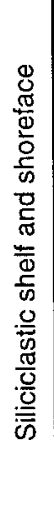 } & Pris: & $\begin{array}{l}\text { Coarse, tabular-bedded } \\
\text { sandstone }\end{array}$ & $\begin{array}{l}\text { Coarse- to pebbly immature sandstone. Tabular beds. Planar lamination. Wave } \\
\text { ripples and local desication cracks. }\end{array}$ \\
\hline & $\because$ & $\begin{array}{l}\text { Fine- to medium cross- } \\
\text { bedded sandstone }\end{array}$ & Fine- to medium sandstone. Large $(1-2 \mathrm{~m})$ cross beds. \\
\hline & $\because \because$ & $\begin{array}{l}\text { Shale, siltstone and } \\
\text { fine sandstone }\end{array}$ & $\begin{array}{l}\text { Green and red shale, siltstone and fine sandstone arranged in } 1 \text { to } 10 \mathrm{~m} \text { thick } \\
\text { upward-coarsening parasequences. Abundant planar lamination, ripple lamination } \\
\text { and wave ripple forms in sandstone sub-facies. Trough cross-stratification and } \\
\text { hummocky cross-stratification also present but more rare. }\end{array}$ \\
\hline & $\because 3$ & Shale and siltstone & Green or red shale and siltstone. Rare thin beds of sandstone and gutter casts. \\
\hline & $\Delta \mathbf{A}$ & Tillite & $\begin{array}{l}\text { Diamictite, not restricted to valley fill. Associated laminites and } \\
\text { dropstones. Interpreted as giaciogenic. }\end{array}$ \\
\hline & soi & Valley fill & $\begin{array}{l}\text { Valley-fill deposit composed of conglomerate, diamictite, laminated siltstone and } \\
\text { sandstone. }\end{array}$ \\
\hline
\end{tabular}

FIG. 4.-Characteristics of depositional facies. 
sal Nama Group) corresponds to a gradational change in lithology, but there is no evidence for a corresponding change in water depth. The gradational transition is interpreted as evidence for conformity between the Witvlei and Nama groups (Hegenberger 1993); it is interpreted as a sequence boundary that correlates updip with an unconformity.

Naukluft Nappe Complex.-Possible stratigraphic equivalents of the Witvlei Group in the Naukluft Nappe Complex include the Blässkrans, Tsabisis, and Bullsport formations. The 200 m thick Blässkrans Formation includes a laminated-shale unit, with outsized limestone clasts interpreted as dropstones, and an overlying unit of massive diamictite (Hoffmann 1989; Hoffmann et al. 1995). Massive to laminated, fine-grained, pink/tan dolostone and purple shale of the overlying Tsabisis Formation bear strong resemblance to pink and purple carbonate and shale facies of the lower Buschmannsklippe Formation, $100 \mathrm{~km}$ to the northeast (Hoffmann 1989; Hoffmann et al. 1995). In addition, carbonates of the Bullsport Formation contain crystal fans.

Carbon-Isotope Variations.-Dolostones from the Court Formation yielded a wide range in $\delta^{13} \mathrm{C}$ values $(-4.3$ to $+5.8 \%$; Fig. $2 \mathrm{~A})$. Significantly, the most negative $\delta^{13} \mathrm{C}$ values are from samples near the base of the formation. Positions of highly ${ }^{13} \mathrm{C}$-enriched samples are uncertain, however, because of the multiple collection localities. Diagenetic alteration in a restricted or lacustrine basin may account for the isotopic variations of the Court Formation. Still, given the marine-like facies and the position of the Court Formation directly above glaciogenic rocks, it seems consistent that the carbon-isotope variations are primary and similar to other negativeto-positive $\delta^{13} \mathrm{C}$ excursions documented above Neoproterozoic glacial horizons (Kaufman and Knoll 1995; Kaufman et al. 1997).

$\delta^{13} \mathrm{C}$ values from the Buschmannsklippe Formation decrease from $-2.6 \%$ near the base of the formation to a minimum near $-5 \%$ corresponding to the calcite fans and other facies associated with the zone of maximum flooding. Values then increase up section to near $-3.5 \%$ at the top of the Okambara Member.

Absolute values and stratigraphic trends of carbon-isotope compositions from the Naukluft Nappe Complex resemble those of the Buschmannsklippe Formation (Fig. 2A, B). In addition, ${ }^{87} \mathrm{Sr} /{ }^{86} \mathrm{Sr}$ in limestone from the basal La Fraque Member near Gobabis and the Tsabisis Formation of the Naukluft Nappes Complex are indistinguishable (ca. 0.7081; Kaufman et al. 1993; A.J. Kaufman, unpublished data 1997). These comparisons strengthen lithostratigraphic correlation of the Tsabisis and Buschmannsklippe formations and support interpreting both as part of the same depositional sequence, deposited during sealevel rise coincident with the end of Blässkrans glaciation.

\section{Kuibis Subgroup}

The Kuibis Subgroup is the only stratigraphic unit preserved in each of the four geographic areas. Consequently, it is of primary importance for correlation (Fig. 3). The Kuibis Subgroup is thickest near the Damara and Gariep belts; it thins and pinches out as it encroaches the Osis arch (Germs 1983; Gresse and Germs 1995). It consists of the sandstone-dominated Dabis Formation and the carbonate-dominated Zaris Formation, which are further subdivided in each of the areas. Carbonate members in the Kuibis Subgroup record a complete positive carbon-isotope excursion with negative $\delta^{13} \mathrm{C}$ values near the base similar to those of the underlying sequence (W2; Buschmannsklippe Formation), a rise to positive $\delta^{13} \mathrm{C}$ values through the middle, and a return to $\delta^{13} \mathrm{C}$ values near zero at the top (Fig. 3). Only two depositional sequences are well preserved in most described localities, but through chemostratigraphic correlation a total of three different sequences (K1, K2, and K3) are distinguished (Fig. 3).

Sequence K1.-Sequence K1 is characterized isotopically by negative $\delta^{13} \mathrm{C}$ values. It is recognized in the Gobabis area, at Zaris Pass in the Northern Nama sub-basin, and across much of the southern part of the southern Nama sub-basin (Fig. 2). At other studied localities, such as at
Zebra River, Mooifontein, and Schlip, it is either absent or is very thin and has not been recognized (Fig. 3). Sequence K1 consists of a basal unit of coarse, tabular-bedded sandstone, with small wave ripples and desiccation cracks, interpreted to have been deposited in a tidal-flat environment. In the Gobabis area K1 sandstone (Weissberg Member) gradationally overlies mixed carbonate and sandstone of the upper Buschmannsklippe Formation. In the northern and southern Nama sub-basins, K1 sandstone (Kanies Member) unconformably overlies older strata or nonconformably overlies crystalline basement.

The upper part of sequence K1 consists predominantly of carbonate. In the Gobabis area and near Swartkloofberg, fine-grained, irregularly laminated dolostone and limestone, with rare, dolomitized, mud-cracked tidalflat caps (Zenana Member and Mara members) are interpreted to have been deposited largely in shallow, wave-influenced environments. Fenestral, microbial dolostone, grainstone, and sandstone developed at Zaris Pass (Mara Member) represent more restricted environments.

Sequence K2.-Sequence K2 is distinguished by positive, upward-increasing $\delta^{13} \mathrm{C}$ values that define the rising limb of a positive excursion. Similarly to sequence K1, it consists of sandstone (Kliphoek and upper Zenana members) overlain by carbonate (Zaris Formation).

Sandstone facies are thickest in the Gobabis area and near Swartkloofberg in the southern Nama sub-basin, where they overlie sequence K1. The sequence boundary is locally erosional with relief of a meter or more. Medium-grained, thick-bedded, cross-bedded sandstone is interpreted as upper-shoreface, delta- or tide-influenced deposits that prograded across the underlying carbonate platform during sealevel lowstand and were trapped during transgression (Saylor et al. 1995). Near the Osis arch and across much of the northern Nama sub-basin, where sequence K2 overlies crystalline basement, the basal sandstone is coarse grained and tabular bedded. Abundant basement-derived lithic fragments indicate trapping of detritus during large-scale transgression of the craton.

The upper part of sequence $\mathrm{K} 2$ is part of an extensive carbonate platform (Zaris Formation) that thickens northward toward the Damara belt (Germs 1983). The platform maintains a relatively constant thickness (30-40 m) over the southern Nama sub-basin, pinching out only in the immediate vicinity of Osis. It reaches a maximum thickness of $500 \mathrm{~m}$ along the Zebra River in the northern Nama sub-basin. Carbonate facies grade laterally northward from Zebra River into laminated limestone and shale in the Gobabis area.

The upper part of sequence K2 in the northern Nama sub-basin (Omkyk Member) consists of three upward-coarsening successions (Germs 1983), recognized across the northern sub-basin (Figs. 3, 5). Each reaches a maximum thickness of tens of meters, and shoals upward from middle-shoreface facies such as massive to hummocky cross-stratified calcisiltite or heterolithic interbeds, to upper-shoreface facies consisting of cross-stratified grainstone, commonly overlain by stromatolitic buildups (Figs. 2C, 3).

South of Osis, sequence K2 carbonate constitutes the Mooifontein Member of the Zaris Formation (Figs. 2, 3). It consists of thin-bedded limestone with graded beds, ripple lamination, and intraclast breccias indicative of storm reworking (Kreisa 1981). Little change in the thickness of these facies suggests deposition across a broad region of low relief during flooding of the craton.

In the northern Nama sub-basin sequence K2 is conformable with sequence K3, the youngest part of the Kuibis Subgroup. South of Osis, however, the top of sequence K2 is an unconformity. Erosional canyons cut into the Mooifontein Member are infilled with conglomerate and overlain by fine siliciclastic rocks of the lower Schwarzrand Subgroup.

Sequence K3.-Sequence K3 is distinguished by positive, upward-decreasing $\delta^{13} \mathrm{C}$ values that define the falling limb of a positive carbonisotope excursion. Sequence K3 is clearly developed only in the northern Nama sub-basin, where it corresponds to the Hoogland and Urikos Members of the Zaris Formation. Middle-shoreface heterolithic interbeds overlie a laterally extensive microbial biostrome that defines the top of sequence 


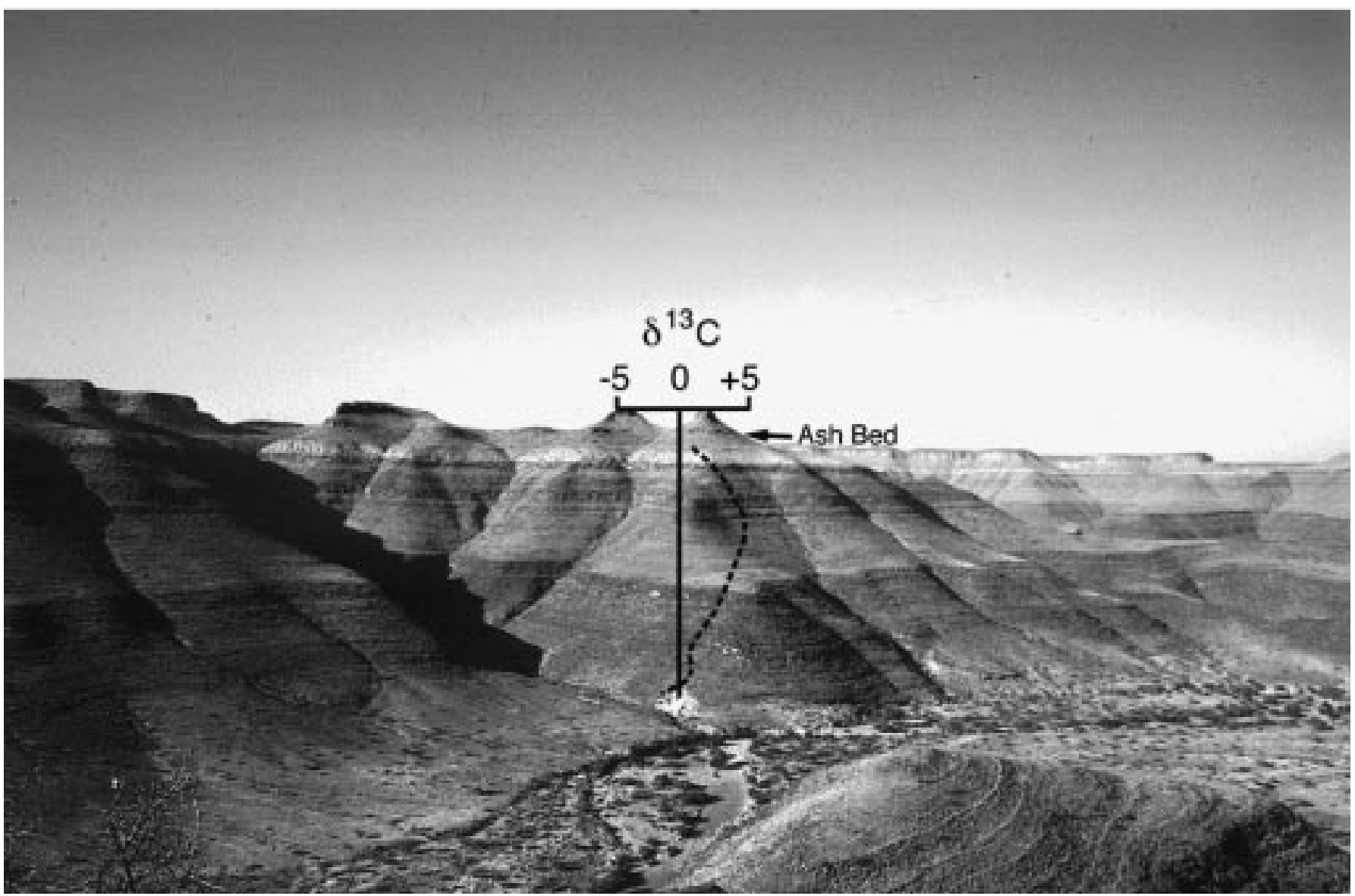

FIG. 5.-Outcrop photograph of the Zebra River section (Fig. 2C) of the Zaris Formation in the northern Nama sub-basin showing position of parasequence boundaries, volcanic ash bed (vvv), and superimposed generalized carbon-isotope profile.

K2. Carbonate facies fine upward and grade into shale and limestone of the lower Urikos Member, which marks the maximum flooding zone. The Urikos Member coarsens upward again through the upper $30 \mathrm{~m}$, where heterolithic interbeds with hummocky cross-stratification and coarsegrained ripples (e.g. Cheel and Leckie 1992) grade upward into sandstone of the overlying Schwarzrand Subgroup. The Hoogland and Urikos Members together form a transgressive-regressive succession interpreted as a depositional sequence. Locally the sequence is conformable with both underlying (K2) and overlying (lower Schwarzrand Subgroup) sequences.

Carbon-Isotope Variations. $-\delta^{13} \mathrm{C}$ values from sequence $\mathrm{K} 1$ (between $\sim-1.5 \%$ and $-3.5 \%$ o are similar to those from subjacent sequence W1, supporting physical stratigraphic evidence that the transition from the Buschmannsklippe Formation to the Kuibis Subgroup is conformable. A single sample from the lower, sandstone-dominated part of sequence K2 (Kliphoek Member) yielded a similar value.

The carbonate-dominated upper part of sequence $\mathrm{K} 2$ shows rising $\delta^{13} \mathrm{C}$ values. Peak values vary from section to section, with the highest values $(+6 \%)$ documented from near Osis. This variability may reflect a combination of incomplete preservation or sampling but also may record variability due to diagenesis or variations in seawater carbon-isotope compositions. Preservation of only the peak of the excursion near Osis reflects the time-transgressive nature of marine transgression and carbonate platform development.

The falling limb of the carbon-isotope excursion is best represented by the Zebra River section in the northern Nama sub-basin. The peak is contained within sequence $\mathrm{K} 2$. Its age is well constrained by a U-Pb zircon date of $548.8 \pm 1 \mathrm{Ma}$, obtained for an ash bed just $15 \mathrm{~m}$ higher (Figs.
2C, 5; Grotzinger et al. 1995). $\delta^{13} \mathrm{C}$ values smoothly decrease through the K2-K3 boundary and through the lower part of sequence K3 (Hoogland Member). They straddle $0 \%$ in the upper part of sequence K3 (Urikos Member). These samples that yielded $\delta^{13} \mathrm{C}$ values near $0 \%$ are depleted in ${ }^{18} \mathrm{O}$, perhaps reflecting the influence of diagenesis, but high $\mathrm{Sr}$ abundances and $\mathrm{Mn} / \mathrm{Sr}$ values less than 2, similar to those from samples lower in the section, suggest that $\delta^{13} \mathrm{C}$ alteration has been minimal.

It is unclear how sequence $\mathrm{K} 3$ correlates across the Osis arch because no sequence boundaries have been traced across the arch and there is no evidence for a matching isotope interval in the southern sub-basin. Sequence K3 may correlate either with the unconformity at the top of the Kuibis Subgroup or, alternatively, with the siliciclastic basal Schwarzrand Subgroup south of Osis. Stratigraphic correlations suggested by Germs (1983) and Gresse and Germs (1995), plus field data from the current study, show no evidence that limestone of sequence K3 grades southward into shale and sandstone of the southern Schwarzrand Subgroup. Most likely sequence K3 correlates with the unconformity at the top of the southern Kuibis Subgroup (Fig. 3).

\section{Schwarzrand Subgroup}

Carbonate strata in the Schwarzrand Subgroup are restricted to the southern Nama sub-basin. The lower part of the Schwarzrand Subgroup, comprising the Nudaus Formation and the Nasep Member of the Urusis Formation, consists, principally, of fine-grained siliciclastic mudstone and sandstone interpreted to have been deposited in a range of tide- and deltainfluenced shoreface environments (Fig. 2D; Germs 1983; Saylor et al. 
A.

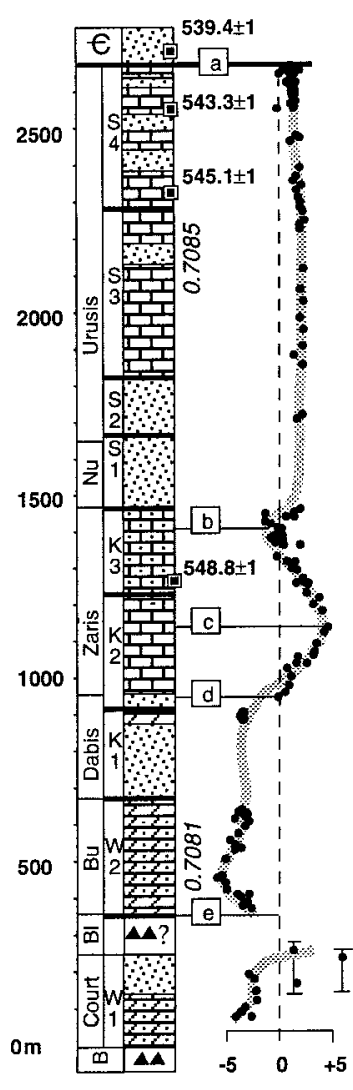

Kalahari Craton, $\delta^{13} \mathrm{C}$ Namibia

\section{DOMINANT LITHOLOGY}

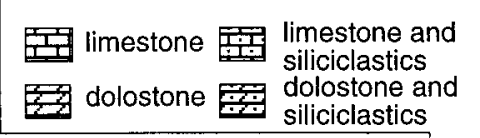

B.

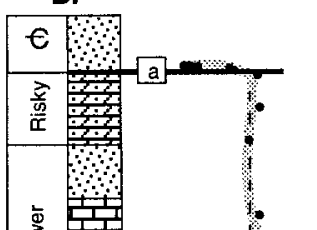

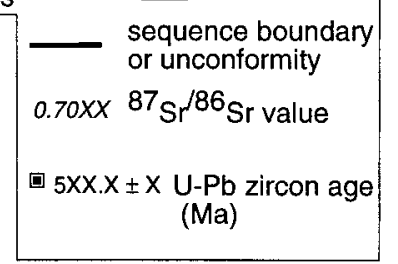

$\because \vdots$ siliciclastics

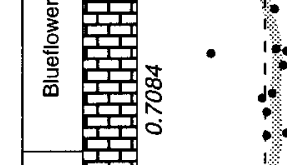

密
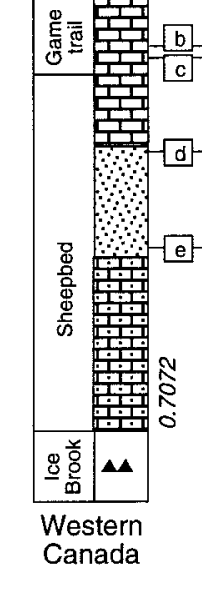

FIg. 6.-Stratigraphic columns (modified from Kaufman and Knoll 1995) showing carbon-isotope excursions, fossil data, the most reliable limestone Sr-isotope values, and glacial horizons in the Namibian reference section and other correlative sections. All sections are drawn to the same scale as the Namibian reference section. Boxed letters are chemostratigraphically defined points of correlation. Sources of data: A) this paper; B) Narbonne et al. (1994), Kaufman et al. (1996); C) Knoll et al. (1986), Fairchild and Spiro (1987), Kaufman et al. (1993), Kaufman et al. (1997); D) Burns and Matter (1993); E) Knoll et al. (1995). Bl, Blässkrans Formation; Bu, Buschmannsklippe Formation; Nu, Nudaus Formation; M, Mastahk Formation.

1995). Two depositional sequences are recognized, S1 and S2, both of which are bounded by erosional surfaces with several meters of relief (Saylor et al. 1995). The middle part of the Schwarzrand Subgroup consists of carbonate platform rocks of the Urusis Formation (Huns, Feldschuhhorn, and Spitskop members). It thickens southwestward to a maximum of nearly a kilometer at Swartpunt (Fig. 2D). Carbonate facies in the lower part of the platform (Huns Member) consist largely of meter-scale, upward-coarsening cycles, composed of stromatolites, calcisiltite, calcarenite, and pellet/ intraclast grainstone (Saylor et al. 1995; Saylor 1996). Pinnacle reefs mark a flooding surface at the top of the Huns Member and are enveloped in green siltstone and shale of the Feldschuhhorn Member (Saylor et al. 1995; Saylor and Grotzinger 1997). Carbonate facies in the upper part of the platform (Spitskop Member) are generally finer grained than in the lower part. They consist of thin-bedded calcisiltite, with locally developed stromatolites and thrombolites, and are interpreted to have been deposited in low-energy, deeper ramp settings, largely near storm wave base (Saylor 1996; Saylor and Grotzinger 1997)

The Proterozoic-Cambrian boundary unconformity caps the carbonate platform. Extensive erosional canyons along this surface (Germs 1983; Saylor and Grotzinger 1997) cut down through the Spitskop Member to the level of the Huns Member (Saylor and Grotzinger 1997). Conglomerate and shallow marine sandstone and shale of the Cambrian Nomtsas Formation partially infill the incised valleys.

Carbon-Isotope Variations. - Carbon-isotope data from the lower and middle Schwarzrand Subgroup lie in a narrow band of moderately positive, relatively invariant values that decrease slightly upward from near $+2 \%$ at the base of the platform to near $+1 \%$ just below the Proterozoic-Cambrian boundary unconformity (Fig. 2D). Ediacaran-type fossils, discovered in the Spitskop Member near the top of the platform, lie above a $543.3 \pm$ 1 Ma volcanic ash bed (Grotzinger et al. 1995). The fossils, the ash bed, and the carbon-isotope data were all collected from the same measured section of the Spitskop Member.

\section{COMPOSITE CHRONOSTRATIGRAPHY}

A composite reference section (Fig. 6A), constructed from the thickest, most complete component section in each area, provides a useful framework for global correlation and comparison. This reference section includes: (1) a lower part from the Gobabis area and Naukluft Nappe Complex (Fig. 2A, B) comprising the Blaubeker Formation, Witvlei Group, and basal Kuibis Subgroup (sequences W1, W2, and K1), plus the Blässkrans glacial unit; (2) a middle part (Fig. 2C) corresponding to sequences K2 and 
K3 of the Kuibis Subgroup in the Zebra River section north of Osis; and (3) an upper part consisting of the Schwarzrand Subgroup from near Swartkloofberg, south of Osis (Fig. 2D).

Two glacial horizons and an intervening interval with variable negative to positive $\delta^{13} \mathrm{C}$ values lie at the base of the reference section. Because of a scarcity of data points and weaknesses in stratigraphic control, the exact form of the isotope profile between the two glacial horizons is unresolved. Still, combined chemostratigraphic, lithostratigraphic, and sequence stratigraphic evidence strongly supports the recognition and distinction of these two separate glacial horizons. From the upper glacial horizon (Blässkrans Formation) upward, correlations are well constrained by chemostratigraphic, sequence stratigraphic, and biostratigraphic ties. One exception is the correlation of sequence K3 with the unconformity at the top of the Sequence K2 south of Osis (Fig. 3). This correlation maximizes the thickness of the composite section and the thickness for which no carbon isotope data are available (Sequences S1 and S2).

The well-resolved carbon-isotope profile extending from the base of sequence W2 up to the Proterozoic-Cambrian boundary strongly resembles previous reconstructions of isotope profiles from Namibia and elsewhere. Modifying the scheme of Pelechaty et al. (1996), distinctive intervals of the isotope profile are here assigned labels to facilitate discussion and global comparison. Postglacial negative $\delta^{13} \mathrm{C}$ values (Npg interval) immediately overlying the Blässkrans Formation are followed by the rising (Pr interval) and falling (Pf interval) limbs of a positive $\delta^{13} \mathrm{C}$ excursion, and, in turn, by an interval of relatively invariant, positive $\delta^{13} \mathrm{C}$ values (I interval) that extends up to the Proterozoic-Cambrian boundary unconformity. U-Pb zircon dates place age constraints on the base of the Pf interval $(>548.8 \pm$ $1 \mathrm{Ma})$ and the top of the I interval $(<543.3 \pm 1 \mathrm{Ma})$. The most reliable ${ }^{87} \mathrm{Sr} /{ }^{86} \mathrm{Sr}$ values available for limestones in the succession range from 0.7081 near the base of the Npg interval to 0.7085 in the I interval (Kaufman et al. 1993).

Major gaps in the carbon-isotope profile are siliciclastic-dominated intervals at the bases of sequences $\mathrm{K} 1$ and $\mathrm{K} 2$ and throughout most of sequences S1 and S2. Gaps in the record associated with unconformities were minimized as much as possible by selecting stratigraphic sections that contain gradational transitions correlative with updip sequence-bounding unconformities. The most significant gaps associated with sequence-boundaries are the Proterozoic-Cambrian boundary unconformity and the angular unconformity between sequences $\mathrm{W} 1$ and $\mathrm{W} 2$, which is correlated with the Blässkrans diamictite. Other sequence boundaries are thought to be conformable or, because of the narrow time range constrained by $\mathrm{U}-\mathrm{Pb}$ zircon dates, are inferred to be of relatively short duration. In general, carbonisotope trends show little change across either sequence boundaries or siliciclastic intervals (Figs. 2, 6), supporting the interpretation that the composite section and isotope curve are relatively complete and continuous.

\section{GLOBAL CORRELATIONS}

In general, the composite reference section is similar to one Kaufman et al. (1997) proposed on the basis of a reevaluation of older data (Kaufman et al. 1991). The more detailed and complete isotope record strengthens their arguments that the Blaubeker and Blässkrans formations are two distinct glacial horizons that correlate with the two distinct Varanger glacial horizons of Spitsbergen. Tiepoints along the chemostratigraphic curves shown in Figure 6 indicate preferred correlations among terminal Proterozoic sections. These correlations rely on matching nonunique patterns and, thus, are themselves nonunique. ${ }^{87} \mathrm{Sr} /{ }^{86} \mathrm{Sr}$ values, which appear to increase monotonically upward through terminal Proterozoic rocks, help resolve the ambiguity of correlating multiple carbon-isotope excursions and glacial horizons.

Thus, sequence W1 (Court Formation) is correlated with carbonate overlying the older of the Varanger glacial horizons in Spitsbergen and with the glaciogenic Ice Brook Formation of Canada, both of which yielded negative $\delta^{13} \mathrm{C}$ and low ${ }^{87} \mathrm{Sr} /{ }^{86} \mathrm{Sr}(<0.7072)$ values. Sequence W2 (Buschmannsklippe Formation), which also is characterized by negative $\delta^{13} \mathrm{C}$ values but yielded high ${ }^{87} \mathrm{Sr} /{ }^{86} \mathrm{Sr}$ (ca. 0.7081), is correlated with the younger of the two Varanger tillite units. Highly ${ }^{12} \mathrm{C}$-enriched limestone of the Shurman Formation of Oman and the siliciclastic-dominated middle Sheepbed Formation of Western Canada both separate positively directed carbonisotope excursions; they may include Npg-equivalent rocks even though no associated glacial rocks are recognized.

High ${ }^{87} \mathrm{Sr} /{ }^{86} \mathrm{Sr}$ and the presence of diverse Ediacaran fossils above sequence K1 support correlation of the Pr, Pf, and I intervals with similar patterns on profiles from Ediacaran-fauna-bearing successions in western Canada, Oman, and Siberia. Even details of the profiles, such as the excursion to slightly negative $\delta^{13} \mathrm{C}$ values that defines the top of the Pf interval and the gradual decrease through the I interval, are recognizable in most of these sections. In Siberia and Canada (Narbonne et al. 1994; Knoll et al. 1995; Pelechaty et al. 1996) there is also a sharp negative carbonisotope excursion (NsubC interval) just above the I interval and immediately below the Proterozoic-Cambrian boundary, which is inferred to be contained within the Proterozoic-Cambrian boundary unconformity in Namibia (Grotzinger et al. 1995).

Other correlations are possible. For example, one can argue that the Ice Brook and Blässkrans glacial units are equivalent and the carbon-isotope profile through the Sheepbed Formation reflects added detail not seen in other post-Varanger successions. This correlation, however, results in a large difference between ${ }^{87} \mathrm{Sr} /{ }^{86} \mathrm{Sr}$ of $\mathrm{Npg}$ limestone. Alternatively, given the consistently high ${ }^{87} \mathrm{Sr} /{ }^{86} \mathrm{Sr}(0.7086)$ measured through the entire Oman section, it is worth considering that the section is younger than the preferred correlations show. Correlations based on that approach result in unmatched and more complex carbon-isotope patterns, while improving the strontium fit only somewhat. It seems more reasonable that resetting of the sensitive strontium system accounts for high ${ }^{87} \mathrm{Sr} /{ }^{86} \mathrm{Sr}$ in the predominantly dolomitic Oman section. The preferred correlations best match the known strontium isotope values, while at the same time minimizing the number of isotope excursions and glacial horizons-they are considered the simplest explanation. The implication of these correlations is that ${ }^{87} \mathrm{Sr} /{ }^{86} \mathrm{Sr}$ remained low through and immediately after the first of the two Varanger ice ages and then increased abruptly leading into or immediately after the second, remaining high, or increasing, up through the Proterozoic-Cambrian boundary. More data constraining terminal Proterozoic strontium isotope stratigraphy would constitute a valuable test of the proposed correlations.

\section{EXTRAPOLATION OF AGES}

U-Pb zircon dates from Namibia (Grotzinger et al. 1995) compress the duration of the I interval and overlying NsubC interval to only 5 to 6 million years, compared to earlier estimates of 20-40 m.y. (Knoll and Walter 1992). Given this reevaluation it is worth examining how interpretation of the older part of the record might be affected by compression of the younger part.

As a visual method for comparing average sediment accumulation rates, Figure 7 graphically correlates (Shaw 1960; Shaw 1964; Mann and Lane 1995) isotopic tiepoints from the Namibian reference section with equivalent tiepoints in Canada and Oman. The split in the Canada-Namibia correlation reflects uncertainty about the thickness of Npg interval in western Canada. Almost all slopes are less than one, indicating that for each isotope interval average sediment accumulation rates were greatest in the Namibian reference section, as can be seen by comparing thicknesses (Fig. 6). In addition, there is a sharp bend at the boundary between the Pr and Pf intervals; a shallowing of slopes indicates a relative increase of sediment accumulation rate through the Pf and I intervals in the Namibian reference section compared to Oman and Canada. This increase is relative; in absolute terms, average sediment accumulation rates could have slowed in the other successions while remaining constant in Namibia. Since the lower 
Maximum sediment accumulation rate in Namibia: 400 m/m.y.

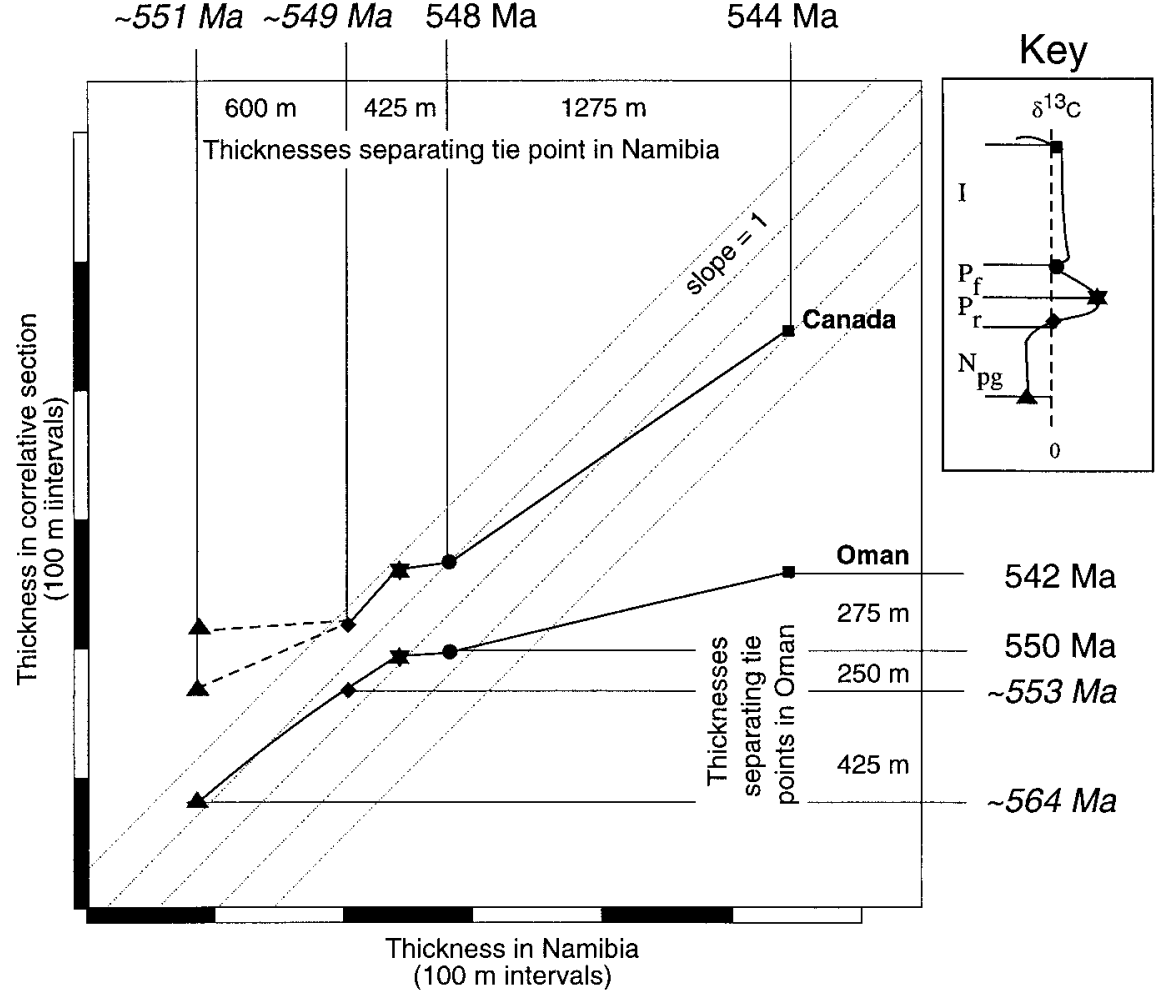

हે

FIg. 7.-Graphic correlation of Namibian reference section with correlative comparison sections in Oman and arctic Canada indicates that average sediment accumulation rate in Namibia increased through the $P_{f}$ and I intervals relative to comparison sections. Downward extrapolation of sediment accumulation rates calculated for the I interval in Namibia and Oman yield maximum and minimum estimates for ages of stratigraphically lower chemostratigraphic tiepoints. part of the Namibian reference section is interpreted to have been deposited on a passive margin and the upper part in a foreland basin (Germs 1983; Hegenberger 1995), however, and since foreland basin subsidence is expected to increase over time (Allen and Homewood 1986), the most likely effect was that of an absolute increase in the subsidence and hence sediment accumulation rate in Namibia.

Assuming constant average sediment accumulation in Namibia and extrapolating the maximum possible rate $(400 \mathrm{~m} / \mathrm{m} . \mathrm{y}$. $=1400 \mathrm{~m} / 3.5 \mathrm{~m} . \mathrm{y}$. $)$ for the I interval yields minimum estimates of 549 Ma for the base of the Pr interval and $551 \mathrm{Ma}$ for the base of the Npg interval. Alternatively, assuming constant average sediment accumulation through the entire Oman section and extrapolating the minimum possible rate for the I interval there $(38 \mathrm{~m} / \mathrm{m} . \mathrm{y}$. $=275 \mathrm{~m} / 7.3 \mathrm{~m} . \mathrm{y}$.) yields maximum age estimates of $\sim 553$ Ma for the base of the Pr interval and $\sim 564$ Ma for the base of the Npg interval. Albeit only very rough estimates, extrapolated ages for tie points along the isotope curve in Namibia illustrate the point that glaciation in Namibia ended significantly after the 600 to 590 Ma age range commonly considered to represent the span of the Varanger glaciation (Knoll and Walter 1992). This graphical exercise suggests that the Varanger glacial epoch, as a whole, may have spanned tens of millions of years beginning as early as $600 \mathrm{Ma}$, as commonly is suggested, and ending some time after $564 \mathrm{Ma}$. The Npg interval is here estimated to have lasted 2-11 m.y. and the Pr and Pf intervals combined to have lasted 1-8 m.y.

\section{DISCUSSION AND CONCLUSIONS}

The estimated duration for the positive carbon-isotope excursion (between 1 and 8 m.y.) compares well with the durations of other better known positive carbon-isotope excursions such as the Middle Miocene, end Paleocene (Shackleton 1987), or Cenomanian-Turonian boundary (Arthur et al. 1987) events. Although the magnitude of the excursion (to $\delta^{13} \mathrm{C}$ values of $+7 \%$ globally) is larger than for most Phanerozoic analogs, enhanced burial of organic carbon still seems a reasonable causal mechanism.

The magnitude, duration, and mechanism behind the Npg interval are more problematic. The magnitude of the negative excursion $\left(\delta^{13} \mathrm{C}\right.$ values $<-5 \%$ globally) is so great that it seems incompatible with whole-ocean changes. Partitioning of the ocean carbon system into reservoirs, one of which is very enriched in ${ }^{12} \mathrm{C}$, may be required (Kaufman et al. 1997). Mechanisms proposed to account for Neoproterozoic negative isotope values focus on bringing to the surface ${ }^{12} \mathrm{C}$-enriched, supersaturated deep waters via either ocean overturning (Kaufman et al. 1991; Grotzinger and Knoll 1996; Kaufman et al. 1997) or transgression-induced upwelling (Kennedy 1996). The first scenario restricts postglacial negative isotope excursions to a very short time interval, on the order of the residence time of carbon in the oceans $\left(10^{5} \mathrm{yr}\right.$; Kaufman et al. 1997). The second restricts ${ }^{12} \mathrm{C}$-enriched carbonates largely to the more basinal settings of upwelling zones, and principally to the distinctive precipitated facies of cap carbonates (Kennedy 1996). Neither scenario is fully compatible with the great thickness and variety of facies spanned by the Npg interval in Namibia. Deposition of the $600 \mathrm{~m}$ of largely typical marine facies that constitute sequence $\mathrm{W} 2$ and $\mathrm{K} 1$ in less than $10^{5} \mathrm{yr}$ seems untenable. In addition, highly negative $\delta^{13} \mathrm{C}$ values are clearly developed in shoal-water and tidal-flat facies, as well as in the distinctive laminated facies typical of carbonates overlying glacial units. A combination of both whole-ocean enrichment in ${ }^{12} \mathrm{C}$ (released from organic matter) to account for ${ }^{12} \mathrm{C}$-enriched shoal-water carbonates of sequence $\mathrm{K} 1$ and sampling of an even more ${ }^{12} \mathrm{C}$-enriched reservoir to account for highly ${ }^{12} \mathrm{C}$-enriched facies of sequence $\mathrm{W} 2$ seems more probable. ${ }^{12} \mathrm{C}$ enrichment of precipitated carbonates may have been enhanced by increased carbonate ion fractionation in seawater with elevated carbonate ion concentrations (Spero et al. 1997). 


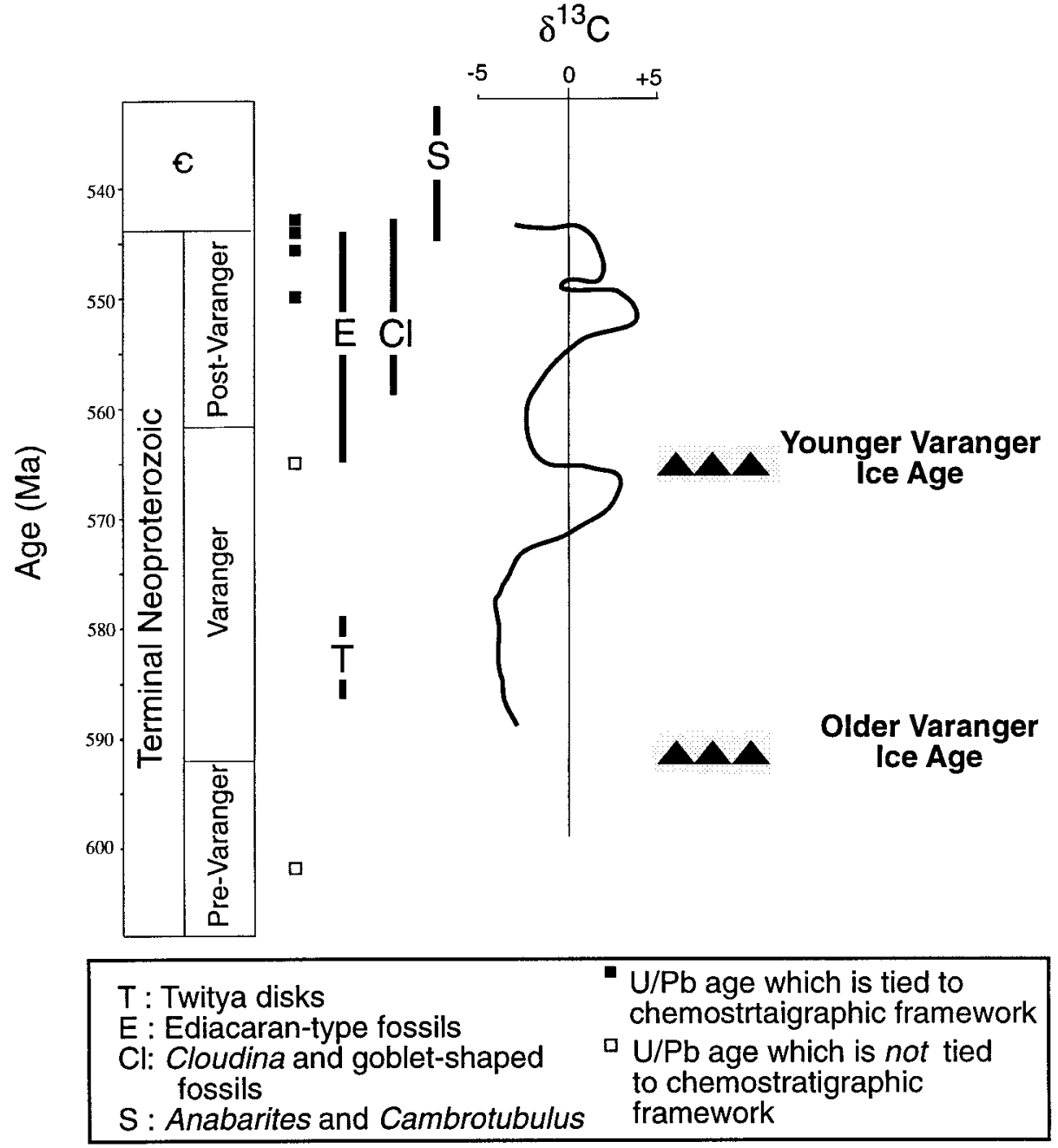

FIG. 8.-Suggested revised terminal Proterozoic chronostratigraphy calibrated with respect to available $\mathrm{U}-\mathrm{Pb}$ zircon age constraints.
The new age constraints (Grotzinger et al. 1995) and the recognition of multiple glacial episodes and associated carbon-isotope excursions (Kaufman et al. 1996) expand the interval spanned by Varanger glaciation and shrink the post-Varanger terminal Proterozoic epoch (Fig. 8). Rather than a single period of intense and widespread glaciation (Harland 1964), the Varanger glacial epoch may be interpreted, instead, as multiple discrete glaciations, possibly of more local distribution, but recorded globally as changes in seawater chemistry. The distinctive facies and relative enrichment in ${ }^{12} \mathrm{C}$ that characterize carbonate rocks overlying Neoproterozoic glacial tillites are not singular anomalies but, instead, are repeated features related to the dynamics of ocean circulation and changes in carbon burial and exhumation associated with periods of ice expansion and retreat (Kaufman et al. 1991; Tucker 1992; Grotzinger and Knoll 1995; Knoll et al. 1996; Kaufman et al. 1997).

A possible corollary of this interpretation is that younger negative-topositive carbon-isotope excursions, at the top of the Kuibis Subgroup in Namibia, and at the Proterozoic-Cambrian boundary in arctic Canada and Siberia, may also be related to similar oceanographic events and climate deterioration (Kaufman et al. 1991), but perhaps without preservation of extensive tills or other glaciogenic facies. Features of possible glacial origin, including iron-formation, diamictite, and groove marks, have been reported from the Kuibis-Schwarzrand boundary in Namibia (Schwellnus 1942; Germs 1995), close to the muted negative-isotope excursion at the top of the Kuibis Subgroup. In addition, stacked karst-capped, shallowingupward cycles in carbonate platform rocks of the middle Schwarzrand Subgroup (Saylor et al. 1995; Saylor 1996) resemble carbonate cycles formed during other major periods of glaciation in Earth history (Read 1996). Combined with the impressive erosional canyons at the Proterozoic-Cambrian boundary, they indicate high-frequency and high-amplitude relative sealevel oscillations during Schwarzrand deposition. Although tectonic forces may have driven these relative sealevel changes in the tectonically active Nama foreland basin, the unconformity recognized at the Proterozoic-Cambrian boundary is present worldwide (Runnegar et al. 1995), suggesting a possible eustatic origin. Sedimentologic and isotopic evidence for glaciations near the Proterozoic-Cambrian boundary have been regarded with skepticism (Saylor et al. 1995), in part because they were thought to be tens of millions of years younger than the Varanger glacial epoch. Within the framework of the timescale proposed here, however, they postdate the younger of the two Varanger glaciations by only a few million years and may be regarded as the last pulses of an extended glacial epoch, which featured repeated episodes of ice expansion and retreat.

The recognition of multiple terminal Proterozoic glacial episodes has implications for understanding the relationship between the Ediacaran radiation and glaciation. Chemostratigraphic correlations of fossil horizons in Canada indicate that the range of large, discoidal Ediacaran-type fossils extends down near to, or below, the horizon equivalent to the younger of 
the Varanger tillites (Kaufman et al. 1997). In addition, the age of diverse Ediacaran fossils in Newfoundland overlaps with the estimated age of the Younger Varanger glaciation. These relationships suggest that the rise and fall of Ediacaran organisms may have overlapped with the waxing and waning of ice sheets.

\section{ACKNOWLEDGMENTS}

This research was supported by National Science Foundation grants EAR9205479 and EAR-9058199 to JPG and EAR 9510339 and EAR-9610339 to P. Hoffman and AJK. The Geological Survey of Namibia provided logistical support. National Science Foundation grant EAR 93-16238 to A. Knoll provided AJK the opportunity to visit Namibia. Charlie Hoffmann and members of the IGCP project 320 field trip to Namibia provided many ideas and stimulating conversation on the outcrop. Reviews by Nic Beukes, Peter Gresse, and an anonymous reviewer improved the manuscript and are greatly appreciated. Preparation of this manuscript was completed at the Department of Geology and Geophysics, University of Wisconsin at Madison.

The data described in the Appendix have been archived, and are available in digital form at the World Data Center-A for Marine Geology and Geophysics, NOAA/NGDC, 325 Broadway, Boulder, CO 80303, U.S.A.; telephone, 303-4976339; e-mail, wdcamgg@ngdc.noaa.gov; URL, http://www.ngdc.noaa.gov/mgg/ sepm/jsr.

\section{REFERENCES}

Artken, J.D., 1991, Two Proterozoic glaciations, Mackenzie Mountains, northwestern Canada: Geology, v. 19, p. 445-448.

Allen, P.A., And Homewood, P., 1986, Foreland Basins: International Association of Sedimentologists, Special Publication 8, 457 p.

Arthur, M.A., Schlanger, S.O., and Jenkyns, H.C., 1987, The Cenomanian-Turonian oceanic anoxic event, II. Paleoceanographic controls on organic-matter production and preservation, in Brooks, J., and Fleet, A.J., eds., Marine Petroleum Source Rocks: Geological Society of London, Special Publication 26, p. 401-420.

Benus, A.P., 1988, Sedimentologic context of a deep-water Ediacara fauna (Mistaken Point Formation, Avalon zone, eastern Newfoundland), in Landing, E., Narbonne, G.M., and Myrow, P., eds., Trace Fossils, Small Shelly Fossils and the Precambrian-Cambrian Boundary: New York State Museum, Bulletin 463, p. 8.

Bowring, S.A., Grotzinger, J.P., Isachsen, C.E., Knoll, A.H., Pelechaty, S.M., and Kolosov, P., 1993, Calibrating rates of Early Cambrian evolution: Science, v. 261, p. 1293-1298.

Burns, S.J., AND MatTER, A., 1993, Carbon isotope record of the latest Proterozoic from Oman: Eclogae Geologicae Helvetiae, v. 86, p. 595-607.

Cheel, R.J., And LeCKIE, D.A., 1992, Coarse-grained storm beds of the upper Cretaceous Chungo Member (Wapiabi Formation), southern Alberta, Canada: Journal of Sedimentary Petrology, v. 62, p. 933-945.

Crimes, T.P., And Germs, G.J.B., 1982, Trace fossils from the Nama Group (PrecambrianCambrian) of Southwest Africa (Namibia): Journal of Paleontology, v. 56, p. 890-907.

DerRy, L.A., KaUfMan, A.J., and JaCobSen, S.B., 1992, Sedimentary cycling and environmental change in the late Proterozoic: evidence from stable and radiogenic isotopes: Geochimica et Cosmochimica Acta, v. 56, p. 1317-1329.

Fairchild, I.J., AND HambreY, M.J., 1995, Vendian basin evolution in East Greenland and NE Svalbard: Precambrian Research, v. 73, p. 217-233.

FairChiLd, I.J., AND SPIRO, B, 1987, Petrological and isotopic implications of some contrasting late Precambrian carbonates, NE Spitsbergen: Sedimentology, v. 34, p. 973-989.

GeRms, G.J.B., 1972, The stratigraphy and paleontology of the lower Nama Group, South West Africa: University of Cape Town, Precambrian Research Unit, Bulletin 12, 250 p.

GeRMS, G.J.B., 1983, Implications of a sedimentary facies and depositional environmental analysis of the Nama Group in Southwest Africa/Namibia, in Miller, R.McG., ed., Evolution of the Damara Orogen: Geological Society of South Africa, Special Publication 11, p. 89114.

Germs, G.J.B., 1995, The Neoproterozoic of southwestern Africa, with emphasis on platform stratigraphy and paleontology: Precambrian Research, v. 73, p. 137-151.

Germs, G.J.B., Knoll, A.H., and Vidal, G., 1986, Latest Proterozoic microfossils from the Nama Group, Namibia (South West Africa): Precambrian Research, v. 32, p. 45-62.

Grant, S.W.F., 1990, Shell structure and distribution of Cloudina, a potential index fossil for the terminal Proterozoic: American Journal of Science, v. 290-A, p. 261-294.

Gresse, P.G., And Germs, G.J.B., 1993, The Nama foreland basin: sedimentation, major unconformity bounded sequences and multisided active margin advance: Precambrian Research, v. 63 , p. $247-272$.

Grotzinger, J.P., AND Knoll, A.H., 1995, Anomalous carbonate precipitates: is the Precambrian the key to the Permian?: PALAIOS, v. 10, p. 578-596.

Grotzinger, J.P., Bowring, S.A., SAYlor, B.Z., and Kaufman, A.J., 1995, New biostratigraphic and geochronologic constraints on early animal evolution: Science, v. 270, p. 598-604

HaRland, W.B., 1964, Critical evidence for great infra-Cambrian glaciation: Geologische Rundschau, v. 54, p. 45-61.

HaRTNADY, C.J.H., 1978, The structural geology of the Naukluft Nappe Complex and its relationship to the Damara Orogenic Belts, South West Africa [unpublished Ph.D. thesis]: University of Cape Town, $256 \mathrm{p}$.
Hegenberger, W., 1987, Gas escape structures in Precambrian peritidal carbonate rocks: Geological Survey of South West Africa/Namibia, Communications, v. 3, p. 49-55.

Hegenberger, W., 1993, Stratigraphy and sedimentology of the late Precambrian Witvlei and Nama Groups, east of Windhoek: Geological Survey of Namibia, Memoir 17, 82 p.

Hoffmann, K.H., 1989, New aspects of lithostratigraphic subdivision and correlation of late Proterozoic to early Cambrian rocks of the southern Damara Belt and their correlation with the central and southern Damara Belt and the Gariep Belt: Geological Survey of Namibia, Communications, v. 5, p. 59-67.

Hoffmann, K.H., Saylor, B.Z., Grotzinger, J.P., and Hegenberger, W., 1995, Field guide to the Nama, Witvlei and related basins in southern Namibia, Part A: Witvlei Group and equivalents in the Naukluft Nappe Complex: unpublished.

KaufMan, A.J., AND KNoll, A.H., 1995, Neoproterozoic variations in the carbon isotopic composition of seawater: Stratigraphic and biogeochemical implications: Precambrian Research, v. 73 , p. $27-49$

Kaufman, A.J., Hayes, J.M., Knoll, A.H., And Germs, G.J.B., 1991, Isotopic compositions of carbonates and organic carbon from upper Proterozoic successions in Namibia: stratigraphic variation and the effects of diagenesis and metamorphism: Precambrian Research, v. 49, p. 301-327.

Kaufman, A.J., Jacobsen, S.B., and Knoll, A.H., 1993, The Vendian record of Sr- and Cisotopic variations in seawater: Implications for tectonics and paleoclimate: Earth and Planetary Science Letters, v. 120, p. 409-430.

Kaufman, A.J., Knoll, A.H., And Narbonne, G.M., 1997, Isotopes, ice ages, and terminal Proterozoic Earth history: National Academy of Sciences, Proceedings, v. 94, p. 6600-6605.

Kaye, C.A., and Zartman, R.F., 1980, A late Proterozoic Z to Cambrian age for the stratified rocks of the Boston Basin, Massachusetts, USA, in Wones, D.R., ed., The Caledonides in the USA, Proceedings: Virginia Polytechnic Institute, Department of Geological Sciences, Memoir 2, $257 \mathrm{p}$

KenNEDy, M.J., 1996, Stratigraphy, sedimentology, and isotopic geochemistry of Australian Neoproterozoic postglacial cap dolostones: deglaciation, $\delta^{13} \mathrm{C}$ excursions, and carbonate precipitation: Journal of Sedimentary Research, v. 66, p. 1050-1064

Kerans, C., And TinkeR, S.W., 1997, Sequence Stratigraphy and Characterization of Carbonate Reservoirs: SEPM, Short Course 40, $130 \mathrm{p}$

KNoll, A.H., AND WaLter, M.R., 1992, Latest Proterozoic stratigraphy and Earth history: Nature, v. 356, p. 673-678.

Knoll, A.H., Bambach, R.J., Canfield, D.E., and Grotzinger, J.P., 1996, Comparative Earth history and Late Permian mass extinction: Science, v. 73, 452-457.

Knoll, A.H., Grotzinger, J.P., Kaufman, A.J., and Kolosov, P., 1995, Integrated approaches to terminal Proterozoic stratigraphy: an example from the Olenek Uplift, northeastern Siberia: Precambrian Research, v. 73, p. 251-270.

KREISA, R.D., 1981, Storm-generated sedimentary structures in subtidal marine facies with examples from the middle and upper Ordovician of southwestern Virginia: Journal of Sedimentary Petrology, v. 51, p. 823-848.

Krogh, T.E., Strong, D.F., O’Brien, S.J., and PaPeZik, V.S., 1988, Precise U-Pb zircon dates from the Avalon Terrane in Newfoundland: Canadian Journal of Earth Sciences, v. 25, p. 442-453.

Mann, K.O., And Lane, H.R. eds., 1995, Graphic Correlation: SEPM, Special Publication 53, $263 \mathrm{p}$

Milliken, K.L., 1979, The silicified evaporite syndrome-two aspects of silicification history of former evaporite nodules from southern Kentucky and northern Tennessee: Journal of Sedimentary Petrology, v. 49, p. 245-256.

Myrow, P.M., 1995, Neoproterozoic rocks of the Newfoundland Avalon zone: Precambrian Research, v. 73, p. 123-136.

Narbonne, G.M., Kaufman, A.J., And Knoll, A.H., 1994, Integrated chemostratigraphy and biostratigraphy of the Windermere Supergroup, northwestern Canada: implications for Neoproterozoic correlations and the early evolution of animals: Geological Society of America, Bulletin, v. 106, p. 1281-1292.

Narbonne, G.M., Saylor, B.Z., and Grotzinger, J.P., 1997, The youngest Ediacaran-fossils from southern Africa, Journal of Paleontology, v. 71, p. 953-967.

Pelechaty, S.M., Kaufman, A.J., and Grotzinger, J.P., 1996, Evaluation of $\delta^{13} \mathrm{C}$ isotope stratigraphy for intrabasinal correlation: Vendian strata of northeast Siberia: Geological Society of America, Bulletin, v. 108, p. 992-1003.

READ, J.F., 1995, Overview of carbonate platform sequences, cycle stratigraphy and reservoirs in greenhouse and ice-house worlds, in Read, J.F., Kerans, C., Weber, L.J., Sarg, J.F., Wright, F.M., eds., Milankovitch Sea Level Changes, Cycles and Reservoirs on Carbonate Platforms in Greenhouse and Ice-house Worlds: SEPM, Short Course 35., 102 p.

Runnegar, B., Gehling, J.G., Horodyski, R.J., Jensen, S., and Knauth, L.P., 1995, Base of the Sauk sequence is a global eustatic event that lies just above the Precambrian-Cambrian boundary (abstract): Geological Society of America, Abstracts with Programs, v. 270, p. A-330.

SARG, J.F., 1988, Carbonate sequence stratigraphy, in Wilgus, C.K., Hastings, B.S., Kendall, C.G.St.C., Posamentier, H.W., Ross, C.A., and Van Wagoner, J.C., eds., Sea-Level Changes: An Integrated Approach: SEPM, Special Publication 42, p. 155-181.

SAYLOR, B.Z., 1993, Progress report on the sedimentology and stratigraphy of the Kuibis and Schwarzrand Subgroups, Witputs area, southwestern Namibia: Geological Survey of Namibia, Communications, v. 8, p. 127-135.

SAYLOR, B.Z., 1996, Sequence stratigraphic and chemostratigraphic constraints on the evolution of the terminal Proterozoic to Cambrian Nama basin, Namibia [unpublished Ph.D. thesis]: Massachusetts Institute of Technology, Cambridge, Massachusetts, 164 p.

SAYLOR, B.Z., AND GROTZINGER, J.P., 1997, Reconstructions of important Proterozoic-Cambrian boundary exposures through the recognition of thrust deformation in the Nama Group of southern Namibia: Geological Survey of Namibia, Communications, v. 11, p. 1-12.

SAylor, B.Z., GrotZinger, J.P., And Germs, G.J.B., 1995, Sequence stratigraphy and sedimen- 
tology of the Neoproterozoic Kuibis and Schwarzrand subgroups (Nama Group), southwestern Namibia: Precambrian Research, v. 73, p. 153-172.

Schwellnus, C.M., 1942, The Nama tillite in the Klein Kharas mountains, S.W.A.: Geological Society of South Africa, Transactions, v. 12, p. 19-33.

SHACKLETON, N.J., 1987, The carbon isotope record of the Cenozoic: history of organic carbon burial and of oxygen in the ocean and atmosphere, in Brooks, J., and Fleet, A.J., eds. Marine Petroleum Source Rocks: Geological Society of London, Special Publication 26, p. 423-434.

SHAw, A.B., 1960, Quantitative fossil correlations: Geological Society of America, Bulletin, v. 71, p. 1972.

Shaw, A.B., 1964, Time in Stratigraphy: New York, McGraw-Hill, 365 p.

Spero, H.J., Buma, J., Lea, D.W., AND Bemis, B.E., 1997, Effect of seawater carbonate concentration on foraminiferal carbon and oxygen isotopes: Nature, v. 390, p. 497-500.

SumNer, D.Y., AND Grotzinger, J.P., 1996, Herringbone calcite: petrography and environmental significance: Journal of Sedimentary Research, v. 66, p. 419-429.

TUCKER, M.E., 1992, The Precambrian-Cambrian boundary: seawater chemistry, ocean circulation and nutrient supply in metazoan evolution, extinction and biomineralization: Geological Society of London, Journal, v. 149, p. 655-668.
Van Wagoner, J.C., Posamentier, H.W., Mitchum, R.M., JR., Vail, P.R., SArg, J.F., Loutit, T.S., and HardenBol, J., 1988, An overview of the fundamentals of sequence stratigraphy, in Wilgus, C.K., Hastings, B.S., Kendall, C.G.St.C., Posamentier, H.W., Ross, C.A., and Van Wagoner, J.C., eds., Sea-Level Changes: An Integrated Approach: SEPM, Special Publication 42, p. 39-46.

Williams, G.E., 1979, Sedimentology, stable isotope geochemistry, and paleoenvironment of dolostones capping late Precambrian glacial sequences in Australia: Geological Society of Australia, Journal, v. 26, p. 377-386.

Received 18 November 1996; accepted 24 May 1998.

\section{APPENDIX}

The data described in the Appendix have been archived and are available from the World Data Center-A for Marine Geology and Geophysics, NOAA/NGDC. See concluding paragraph of text for information on accessing the data. 